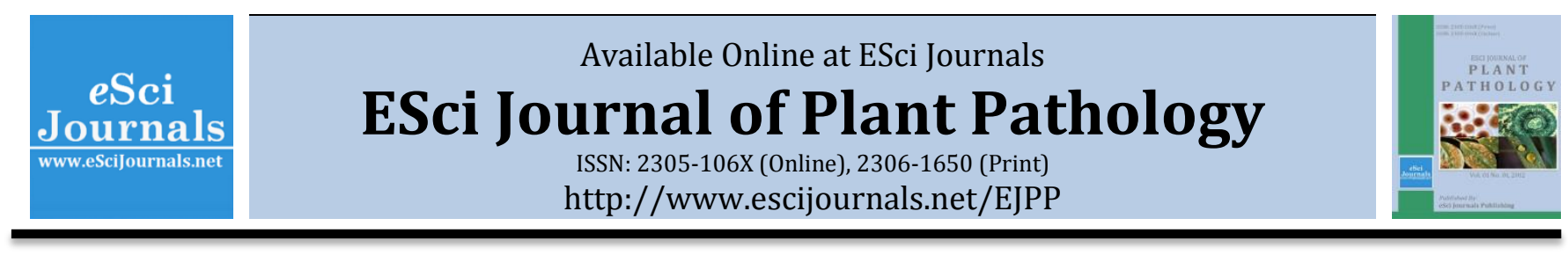

\title{
IN VITRO BIOLOGICAL CONTROL OF BRANCH CANKER (MACROPHOMA THEIOCOLA) DISEASE OF TEA
}

\author{
aIftekhar Ahmad, aMd. Obaidullah, aMohammad A. Hossain, bMohammad Ali, bMd. S. Islam \\ a Department of Food Engineering and Tea Technology, Shahjalal University of Science \& Technology, Bangladesh. \\ b Plant Pathology Division, Bangladesh Tea Research Institute, Srimangal, Bangladesh.
}

\section{A B S T R A C T}

Antagonist microorganisms, such as Trichoderma spp. have long been recognized as biological agents, for the control of plant disease and for their ability to increase root growth and development, crop productivity, resistance to abiotic stresses, and uptake and use of nutrients. An attempt was made to evaluate the in vitro biocontrol of branch canker (Macrophoma theicola) of tea plants by Trichoderma spp. Isolation of Trichoderma spp. and M. theiocola was done carefully. Pure culture of Trichoderma spp. and M. theiocola and their morphological characteristics were studied at different intervals. Five $M$. theiocola and five Trichoderma isolates were collected from mature tea plants and tea soils respectively of Bangladesh Tea Research Institute (BTRI) main farm area. The cultural morphology and antagonistic potentiality of Trichoderma spp. against branch canker pathogen ( $M$. theiocola) were taken into consideration. Trichoderma spp. controls the growth of $M$. theiocola at different intervals. After 24 hour growth rate of Trichoderma was $9.3 \%$ and $M$. theiocola was $0.88 \%$. The antagonistic potentialities of isolated Trichoderma against pathogens $(M$. theiocola) were observed at different intervals (24-120 hrs) and the percentage of inhibition was $82 \%$ which were observed after five days (120 hours) of inoculation. The Trichoderma spp. antagonizes the pathogens by several mechanisms such as antibiosis, competition, mycoparasitism or other form of direct exploitation. From this study it was revealed that, the Trichoderma spp. was highly effective to control the isolates of $M$. theiocola that is responsible for branch canker in tea cultivation.

Keywords: Biological agents, Branch canker, Inhibition activity, Macrophoma theiocola, Trichoderma spp.

\section{INTRODUCTION}

Tea being a perennial crop is prone to attack by many pests and diseases. The majority of the diseases in tea are of fungal origin. More than 400 pathogens cause various diseases in tea (Chen et al., 1990) viz., foliage, stem and root. Branch canker is the most widely prevalent stem disease of tea and many other plants in all the tea growing areas of Bangladesh and North-east India. It is a wound parasite which gains its entrance into the frame of the bush through wounds, especially on the thicker branches caused by various agencies like pruning cuts, sun scorched lesions, damages with ragged surfaces made by carelessly chopping, sawing or wrenching off branches or by falling of shed tree wounds made by hail cattle etc. Chemical control measures have

* Corresponding Author:

Email: iftekharfet.sust@yahoo.com

(C) 2013 ESci Journals Publishing. All rights reserved. been considered as effective in controlling tea diseases so far (Premkumar and Baby, 2005). But, use of fungicides are not most desirable means of disease control as they are cost expensive, causes serious health hazard, environmental pollution and may induce pathogen resistance too (Conzalez and Collazo De Rivera, 1972; Ikediobi, 1985). Biocontrol is a potential, alternative, and eco-friendly way to control the disease which is one of the most interesting aspects of the science of the biological control is the study of the mechanisms employed by biocontrol agents to effect disease control (Howell, 2003). Several attempts were made to control various tea diseases by the application of biocontrol agents such as plants and animal extracts and several microbes (Ahmad et al., 2013; Islam et al., 2013; Hossain et al., 2013; Ali et al., 1993).

Trichoderma is the most important bio-control agent which has been used in different countries for several 
years (Amin et al., 2010). Trichoderma species belong to small family of beneficial fungi that are commonly found in soils nearly all parts of the world. Pathogens that can be controlled by Trichoderma spp. include Pythium, Phytophthora, Fusarium, Rhizoctonia, Sclerotia, and Pestalotia. More than 100 different metabolites from Trichoderma spp., with known antimicrobial activities have been described so far, including antifungal cell wall degrading enzymes, peptaibols and broad-spectrum antibiotics such as gliotoxin (Howell et al., 1993; Lorito et al., 1996; Kim et al., 2002; Wiest et al., 2002; Pozo et al., 2004). From the in vitro study on the biocontrol activity of Trichoderma against Phomopsis theae petch, infecting collar rot of tea, it was found that, Trichoderma was very effective against $P$. theae (Islam et al., 2013).

The advantages of using Trichoderma spp. include: pathogens do not develop resistance against a biocontrol agent, bio-control agents pose no health hazards, environmental hazards and leave no chemical residue on the produce. Several strains of the Trichoderma spp., are found to be effective biocontrol agents for the various plant pathogens (Amin et al, 2010) and they are characterized by rapid growth, abundant conidial formation and a high degree of ecological adaptability reported by Domsch et al. (1980), Papavizas (1985); Bissett (1991). Trichoderma spp. is capable to induce metabolic changes in plants that increase resistance to a wide range of plant-pathogenic microorganisms and viruses (Harman et al., 2004). The mechanisms of mycoparasitism, antibiosis and competition afforded by Trichoderma sp., have been widely studied (Howell, 2003; Harman et al., 2004). This study was focused on the need for screening the isolates of Trichoderma having broad spectrum of antagonistic against stem pathogen $M$. theicola in order to bring efficient biocontrol of Trichoderma against branch canker ( $M$. theicola) pathogen in tea.

\section{MATERIALS AND METHODS}

The experiment was conducted in the Department of Food Engineering and Tea Technology, Shahjalal University of Science and Technology and, Bangladesh Tea Research Institute (BTRI) Sylhet, Bangladesh, 2013.

Isolation of Macrophoma theiocola: $M$. theiocola attacked stems were collected from farm area of Bangladesh tea research institute (BTRI). The PDA media were inoculated with inocula of diseased stems in the petri plates. After that, petri plates were incubated for observing growth of $M$. theiocola and purified by repeated sub culturing and finally transferred to PDA slants. The cultures were sub cultured for getting pure form of the pathogen. The isolates were compared with type strain $M$. theiocola procured from MTCC.

Isolation of Trichoderma spp.: Soil samples were collected from 0-9 inches depth of different marks of tea areas under main farm of Bangladesh Tea Research Institute. All collected soil samples were mixed thoroughly to make a composite sample. 1 gram (dry weight basis) soil sample was taken from composite sample in test tube and mixed into $9 \mathrm{ml}$ of sterile distilled water then $1 \mathrm{ml}$ of suspension was taken into another tube containing $9 \mathrm{ml}$ of sterile distilled water. This serial dilution technique was continued up to 1 : 10,000. From the final dilution (1: 10,000), $1 \mathrm{ml}$ suspension was transferred to each of the five petri plates. $20 \mathrm{ml}$ of melted agar medium was poured in each plate and mixed with the suspension by giving a gentle whirling motion to the plate and allowed them to incubate in room temperature (Islam et al., 2001). Sub culturing was performed and the culture of Trichoderma in pure form was maintained. Colony characterizations were done by observing the growth of the culture.

Interaction with Dual culture method: Potato dextrose agar (PDA) plates were inoculated with $5 \mathrm{~mm}$ mycelial discs $M$. theiocola as well as the antagonist on diametrically, opposite points allowed them to incubate in room temperature for five days. Radial growth of the pathogen and antagonists were measured at $24 \mathrm{hrs}$ intervals and percentage inhibition was calculated using the following formula: $P I=\frac{(A-B)}{A} \times 100$

Where $\mathrm{A}$ is the colony diameter of the fungus in control plates $(\mathrm{mm})$ and $B$ is colony diameter of the fungus in dual cultured plates (mm), PI= Percent of Inhibition.

Statistical analysis: The statistical analysis was done by using MSTAT a computer package. Mean comparison among the different intervals was done by using DMRT.

\section{RESULTS}

The colony characteristics of four Trichoderma spp. isolates were observed different time intervals (24-120 hrs) (Table 01). Colony morphology of Trichoderma isolates were identically similar to each other. After 24 hrs of inoculation, all isolates were shown whitish mycelial growth and after 96 hrs they showed greenish white to dark greenish color (Table 01). Sporulation was started after $72 \mathrm{hrs}$ of incubation at $28 \pm 1^{\circ} \mathrm{C}$ by all the isolates studied. 
Table 1: Colony characters of five isolates of Trichoderma spp.

\begin{tabular}{|c|c|c|c|c|c|}
\hline Isolates & $\begin{array}{c}24 \text { hrs } \\
\left(1^{\text {st }} \text { day }\right)\end{array}$ & $\begin{array}{c}48 \mathrm{hrs} \\
\left(2^{\text {nd }} \text { day }\right)\end{array}$ & $\begin{array}{c}72 \text { hrs } \\
\left(3^{\text {rd }} \text { day }\right)\end{array}$ & $\begin{array}{l}96 \text { hrs } \\
\text { (4th day) }\end{array}$ & $\begin{array}{c}120 \mathrm{hrs} \\
\left(5^{\text {th }} \text { days }\right)\end{array}$ \\
\hline T1 & $\begin{array}{c}\text { Whitish mycelial } \\
\text { growth }\end{array}$ & $\begin{array}{c}\text { Thin whitish } \\
\text { mycelial growth }\end{array}$ & $\begin{array}{l}\text { Dark greenish color } \\
\text { was found around the } \\
\text { mycelial block }\end{array}$ & $\begin{array}{l}\text { Old cultured dark greenish } \\
\text { color and greenish white } \\
\text { margin part }\end{array}$ & $\begin{array}{c}\text { Dark } \\
\text { green } \\
\text { color }\end{array}$ \\
\hline T2 & $\begin{array}{l}\text { A thin white } \\
\text { mycelial growth }\end{array}$ & $\begin{array}{l}\text { White mycelia } \\
\text { growth was } \\
\text { found }\end{array}$ & $\begin{array}{l}\text { Light greenish colored } \\
\text { was found the old part } \\
\text { of the fungal culture }\end{array}$ & Greenish white mycellium & $\begin{array}{c}\text { Greenish } \\
\text { white } \\
\text { colour }\end{array}$ \\
\hline T3 & $\begin{array}{l}\text { White mycelia } \\
\text { growth around } \\
\text { the mycelial disc }\end{array}$ & $\begin{array}{l}\text { Raised white } \\
\text { mycelial growth }\end{array}$ & $\begin{array}{c}\text { Greenish mycelial mat } \\
\text { was formed }\end{array}$ & $\begin{array}{l}\text { Dark greenish mycelial } \\
\text { growth around the } \\
\text { mycelial block }\end{array}$ & $\begin{array}{l}\text { Dark } \\
\text { green } \\
\text { colour }\end{array}$ \\
\hline $\mathrm{T} 4$ & $\begin{array}{l}\text { White mycelial } \\
\text { growth }\end{array}$ & $\begin{array}{l}\text { Same as } 24 \text { hrs } \\
\text { but fluffy } \\
\text { mycelial growth }\end{array}$ & $\begin{array}{l}\text { Greenish mycelial } \\
\text { growth was found and } \\
\text { flattened mycelial } \\
\text { growth around the } \\
\text { mycelial block }\end{array}$ & Greenish white mycelium & $\begin{array}{c}\text { Greenish } \\
\text { white } \\
\text { colour }\end{array}$ \\
\hline
\end{tabular}

The mycelial growths of Trichoderma spp. were increased with the increasing intervals of time (Table 02). The petri dishes were fully covered by the colony after $120 \mathrm{hrs}$ of incubation of Trichoderma spp. on PDA media and Table 2: Mycelial growth (mm) of Tricoderma spp. at different intervals.

\begin{tabular}{cccccc}
\hline \multirow{2}{*}{ Time after plate } & Isolate 1 & Isolate 2 & Isolate 3 & Isolate 4 & Average \\
\cline { 2 - 5 } & \multicolumn{5}{c}{ Average of three replication } \\
\hline $24 \mathrm{hrs}$ & 30 & 30 & 30 & 30 & $30^{\mathrm{e}}$ \\
$48 \mathrm{hrs}$ & 48.33 & 50 & 50 & 50 & $49.58^{\mathrm{d}}$ \\
$72 \mathrm{hrs}$ & 66.66 & 65 & 65 & 66.66 & $65.83^{\mathrm{c}}$ \\
$96 \mathrm{hrs}$ & 81.66 & 80 & 81.66 & 81.66 & $81.25^{\mathrm{b}}$ \\
$120 \mathrm{hrs}$ & 90 & 90 & 90 & 90 & $90^{\mathrm{a}}$ \\
\hline
\end{tabular}

$\mathrm{CV}=1.10 \%, \mathrm{LSD}=1.072 \approx 0.05$

Values showing different letters are statistically different from each other

After inoculation on PDA media Trichoderma spp. grew gradually and covered the plates with white mycelia (Fig. 01).

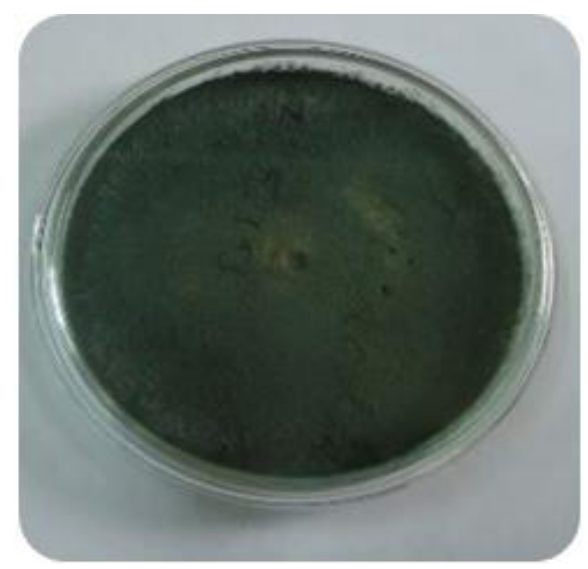

Figure 1. Pure culture of Trichoderma spp. average growth of Trichoderma spp. after five days incubation was $90.00 \mathrm{~mm}$ (Table 02). Growth rate of mycelia of Trichoderma spp. in respect of different interval showed statistically significant (Table 02). The pathogen and antagonist grew until contacting each other and the growth of pathogen got decreased as soon as get contact with Trichoderma spp.

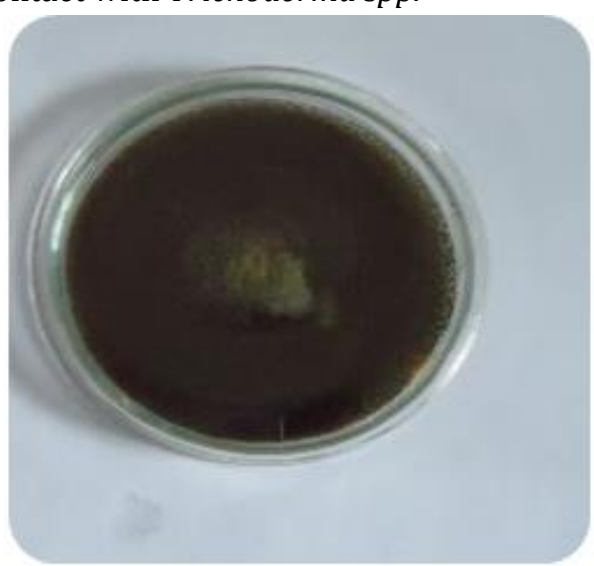

Figure 2. Pure culture of Macrophoma Theiocola. 
In control plates the growth rate of $M$. theiocola increased gradually. After 24 hrs of inoculation the average growth was observed as $10.25 \mathrm{~mm}$, after $48 \mathrm{hrs} 34.99 \mathrm{~mm}$, after $72 \mathrm{hrs} 59.16 \mathrm{~mm}$ and after $96 \mathrm{hrs} 73.91 \mathrm{~mm}$ and after $120 \mathrm{hrs} 90$ $\mathrm{mm}$ (Table 03). Growth rate of mycelia of $M$. theiocola in respect of different interval showed statistically significant (Table 03).

Table 04 reflects that, radial growth rates of Trichoderma isolates became slightly different at the time of contact with the pathogen. The average growth rates of Trichoderma were gradually increased and average growth rates of $M$. theiocola remained constant. After incubation of five days in PDA media the average growth of trichoderma spp. and $M$. theoicola were found73.8 $\mathrm{mm}$ and $16.2 \mathrm{~mm}$ respectively (Table 04).

Table 3. Mycelial growth (mm) Mcrophoma theicola at different intervals.

\begin{tabular}{cccccc}
\hline \multirow{2}{*}{ Time after plate } & Isolate 1 & Isolate 2 & Isolate 3 & Isolate 4 & \multirow{2}{*}{ Average } \\
\cline { 2 - 4 } & \multicolumn{4}{c}{ Average of the three replication } & \\
\hline $24 \mathrm{hrs}$ & 10.33 & 10 & 10.66 & $10.25^{\mathrm{e}}$ \\
$48 \mathrm{hrs}$ & 33.33 & 35 & 36.66 & 35 & $34.99^{\mathrm{d}}$ \\
$72 \mathrm{hrs}$ & 60 & 61.66 & 58.33 & 56.66 & $59.16^{\mathrm{c}}$ \\
$96 \mathrm{hrs}$ & 73.66 & 74.33 & 74 & 73.66 & $73.91^{\mathrm{b}}$ \\
$120 \mathrm{hrs}$ & 90 & 90 & 90 & 90 & $90^{\mathrm{a}}$ \\
\hline
\end{tabular}

$\mathrm{CV}=2.17 \%, \mathrm{LSD}=1.794 \approx 0.05$

Values showing different letters are statistically different from each other.

Table 4. Mycelial growth (mm) of Tricoderma spp. and Macrophoma theiocola in dual culture at different intervals.

\begin{tabular}{|c|c|c|c|c|c|c|c|c|c|c|}
\hline \multirow{3}{*}{$\begin{array}{c}\text { Dual } \\
\text { culture } \\
\text { plate }\end{array}$} & \multicolumn{10}{|c|}{ Radial growth (mm) of Tricoderma spp. and Macrophoma theiocola at different intervals } \\
\hline & \multicolumn{2}{|c|}{24 hrs DAI } & \multicolumn{2}{|c|}{48 hrs DAI } & \multicolumn{2}{|c|}{72 hrs DAI } & \multicolumn{2}{|c|}{96 hrs DAI } & \multicolumn{2}{|c|}{120 hrs DAI } \\
\hline & $\mathrm{T}$ & M & $\mathrm{T}$ & M & $\mathrm{T}$ & M & $\mathrm{T}$ & $\mathrm{M}$ & $\mathrm{T}$ & $\mathrm{M}$ \\
\hline Plate 1 & 8 & 0 & 18 & 6 & 33 & 10 & 55 & 13 & 73 & 17 \\
\hline Plate 2 & 9 & 2 & 18 & 6 & 35 & 9 & 56 & 13 & 74 & 16 \\
\hline Plate 3 & 8 & 1 & 19 & 6 & 34 & 9 & 56 & 14 & 74 & 16 \\
\hline Plate 4 & 8 & 0 & 17 & 5 & 34 & 10 & 55 & 14 & 74 & 16 \\
\hline Plate 5 & 9 & 1 & 18 & 6 & 35 & 10 & 55 & 13 & 74 & 16 \\
\hline Average & 8.4 & 0.8 & 18 & 5.8 & 34.20 & 9.6 & 55.4 & 13.4 & 73.8 & 16.2 \\
\hline
\end{tabular}

DAI=Days after incubation; ( $\mathrm{T}=$ Tricoderma spp. and $\mathrm{M}=$ Macrophoma theiocola).

In dual culture plate the growth of pathogens were retarded due to the presence of Tricoderma. The percentage of mycellial growth of Trichoderma spp. and M. theicola in dual culture at different intervals were

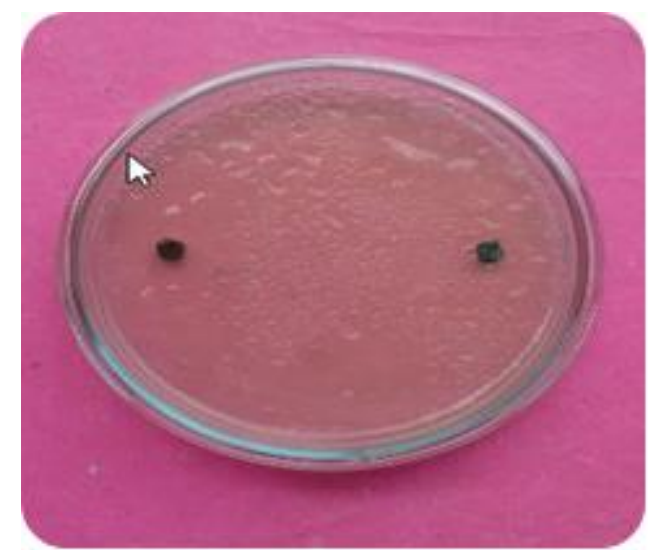

Figure 3. Dual culture observed (Figure 3 and 04). After five days of incubation, only $18 \%$ growth of Macrophoma theicola and $82 \%$ of Tricoderma was occurred (Fig 05).

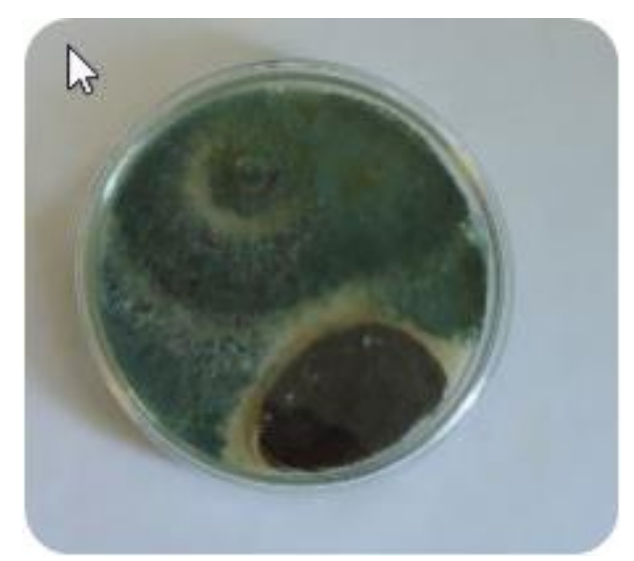

Figure 4. Dual culture of after 5 days. 


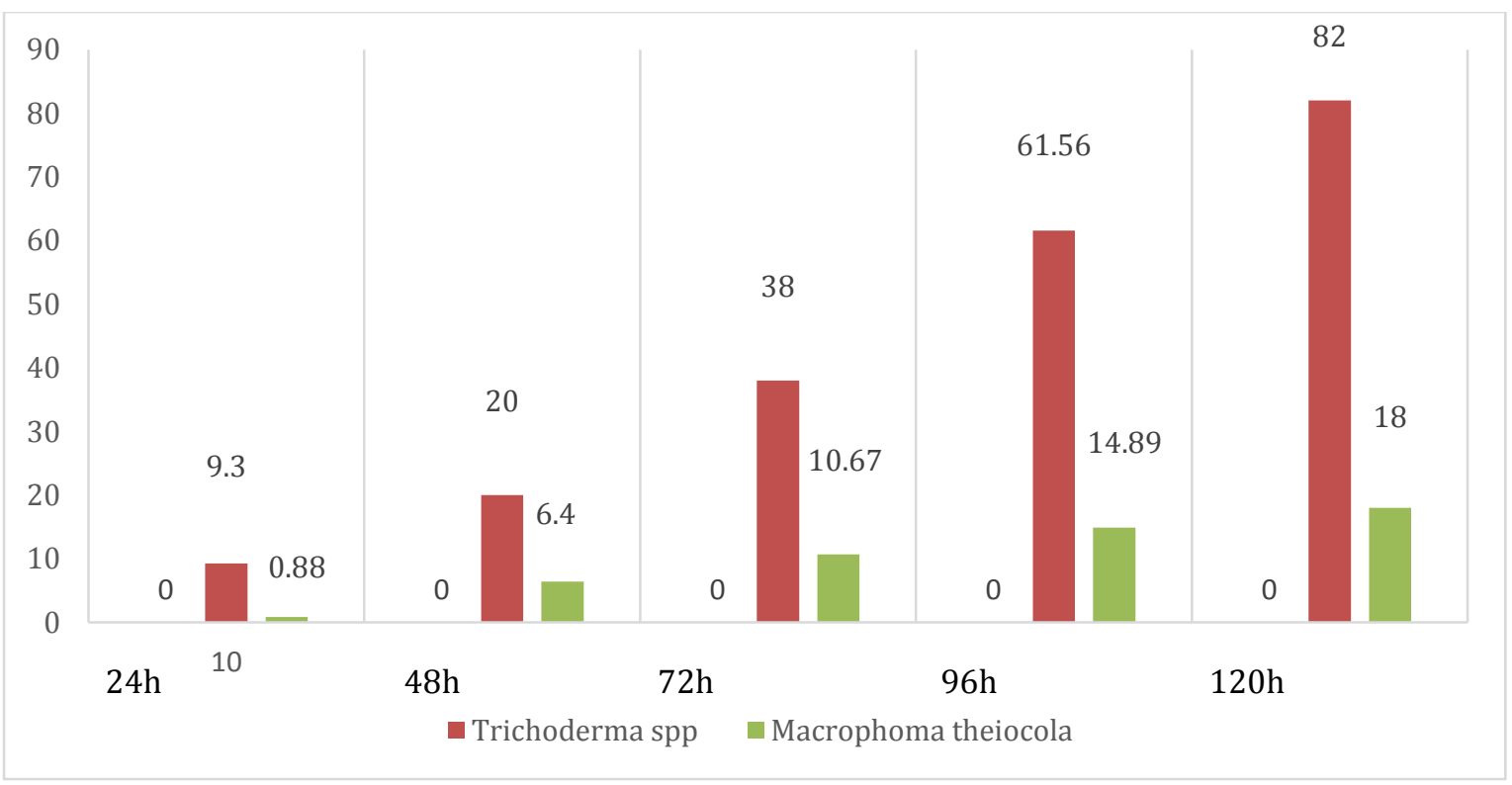

Figure 5. Comparative growth rate (\%) of Thrichoderma \& Macrophoma at different interval.

The graph showed different growth rate of Trichoderma spp. and Macrophoma theiocola. After 24 hours the growth rate of Trichoderma was $9.3 \%$ and Macrophoma was $0.88 \%$. After $120 \mathrm{hrs}$ the growth rate of Trichoderma was $82 \%$ and Macrophoma was $18 \%$. It is clearly observed that Trichoderma growth is higher than Macrophoma (Figure 5).

\section{DISCUSSION}

The colony characterizations were done to isolate the Trichoderma spp. These same trends of results were observed in the Trichoderma spp. against the major fungal pathogen of Branch canker (Kuberan et al., 2012). Such colony characteristics were clearly resembled to that Trichoderma spp. The mycoparasitism grew towards host, ran parallel and coiled around host hyphae by mycoparasitism producing the haustoria knob like structure with penetration peg, penetrated the pathogen hyphae and finally the cytoplasm of pathogens was lysed. Mycoparasitism includes both hyphal interaction and is the most vital mechanism of antagonism of fungal antagonist to give protection to the plants from the pathogen attack. Mycoparasitism as principle mechanism of biological control is favoured by many scientists (Elad et al., 1983).

Table 02 showed the growth rate of the pure culture of Trichoderma spp. After 24 hour the rate is $30 \mathrm{~mm}$ and after 120 hour it is $90 \mathrm{~mm}$. The CV value is $1.10 \%$ and LSD value is $1.072 \approx 0.05$. At the same time the growth rate of the pure culture of Macrophoma theiocola (Table 05) after 24 hours was $10.25 \mathrm{~mm}$ and after 120 hour it was $90 \mathrm{~mm}$. It is clearly observed that Tricoderma spp. and $M$. theiocola covered the whole culture plate after 120 hours (5 days).

Antibiosis and parasitism play an important role in biocontrol of plant diseases. A large number of plant diseases are successfully controlled through bacterial and fungal antagonism. The in vitro antagonism of Trichoderma spp., against stem pathogens of tea was studied. The efficacy of Trichoderma bioformulations in controlling some of the primary and secondary foliar and stem diseases has been reported (Papavizas et al., 1985). The biocontrol agents from plant protection species is the filamentous fungal genus Trichoderma which is of great economic importance as sources of enzymes and antibiotics. Antagonist microorganisms, such as Trichoderma reduce growth, survival or infections caused by pathogens by different mechanisms like competition, antibiosis, mycoparasitism, hyphal interactions, and enzyme secretion (Cook and Baker, 1983).

The radial growth rates of Trichoderma isolates were slightly different at the time of contact with the test pathogen (Macrophoma theiocola). The pathogen and antagonist grew until contacting them each other and the growth of pathogen got distributed as soon as get the contact with Trichoderma. The Trichoderma strains overgrew on the pathogen colony and complete invasion and sporulation occurred after four to five days.

Trihcoderma and M. theiocola showed an increasing and significant radial growth of mycelium at different 
intervals (Table 04). In the dual culture experiment, the pathogen and antagonists grew until they came in contact with each other. Further growth of the pathogen was inhibited, while the antagonists continued their growth and completely covered the pathogen in about five days (Table 04). After $24 \mathrm{hrs}$ of incubation the average growth of M. theiocola and Trichoderma was 0.8 $\mathrm{mm}$ and $8.4 \mathrm{~mm}$ respectively and after $48 \mathrm{hrs}$ the average growth was $5.8 \mathrm{~mm}$ and $18 \mathrm{~mm}$ respectively and increasing in these trends. The average growth rate of Tricoderma is quite faster than M. theiocola. It indicates the inhibition on the growth of the pathogen was $82 \%$ for Trichoderma. Inhibition of the growth of M. theiocola might be due to the diffusible metabolites secreted by the antagonists. The antagonists completely inhibited the mycelia growth of antibiotics which induced swelling and plasmolysis of the cells. (Tasiwall et al.,2009).

From the above discussion we can say that Trichoderma spp. control the growth of $M$. theiocola. So for the biocontrol of branch canker disease Trichoderma spp. was highly effective.

\section{CONCLUSION}

Trichoderma spp. plays an important role in controlling fungal plant pathogens, especially soil borne fungal pathogens. The use of Trichoderma based products is not only safe for the farmers and consumers but also good for the environment. In this study only morphologically Trichoderma spp. isolated based on the colony characterizations. It needs to identify the species clearly to produce formulations and market as a biocontrol product. From this study, we observe that inhibition on the growth of the pathogen was $82.00 \%$ for Trichoderma. It can be concluded that the Trichoderma spp., isolates reduced the growth of the isolates of $M$. theiocola significantly and therefore, can be incorporated into integrated disease management for controlling branch canker disease in tea. The degree of antagonism varied between and within species of Trichoderma spp., against the plant pathogens. Trichoderma spp. can be used for the biocontrol of branch canker disease in tea plant. However, much more work needs to be done to develop stable, cost effective, easy to produce and easy to apply formulations.

\section{ACKNOWLEDGEMENTS}

The authors are highly acknowledged to the Department of Food Engineering \& Tea Technology, Shahjalal University of Science \& Technology (SUST), Sylhet, Bangladesh and Plant Pathology Division, Bangladesh
Tea Research Institute (BTRI), Srimangal, Bangladesh for providing the facilities to carry out this research work.

\section{REFERENCES}

Ahmad, I., M.D. Alam and M.S. Islam. 2012. Antifungal activity of some medicinal plant extracts against Colletorticum gloesporioides (die back) and Pestalotia theae (grey blight) of tea. International J. of Tea Science. 8(4):10-17.

Amin, F., V.K. Razdan, F.A. Mohiddin, K.A. Bhat And S. Banday. 2010. Potential of Trichoderma species as biocontrol agents of soil borne fungal propagules. J. Phytol. 2(10):38-41.

Bissett, J. 1991. A revision of the genus Trichoderma. 2. Infrageneric classification. Can. J. Bot. 69:23572372.

Chen, Z.M. and X.F. Chen. 1990. The diagnosis of tea diseases and their control (in Chinese)9, 73-88 Shanghai scientific and technical publishers, Shanghai, China.

Conzalez, N.A. and A. Collazo-De-Rivera. 1972. Storage of fresh yam (Discorea alata L.) under controlled conditions. J. Agri. Uni. Purerto Rico. 56:46 - 56.

Cook, R.J. and K.F. Baker. 1983. The Nature and Practice of Biological Control of Plant Pathogens. 539, Amer. Phytopathol. Soc. Minnesota. USA.

Domsch, K.H., W. Gams and T.H. Anderson. 1980. Compendium of soil fungi. New York: Academic Press, USA.

Elad, Y., R. Barak, I. Chet and Y. Henis. 1983. Ultra structural studies of the interaction between Trichoderma spp. and plant pathogenic fungi. Phytopathol. 107:168-175.

Harman, G.E., C.R. Howell, A. Viterbo, I. Chet and M. Lorito. 2004. Trichoderma species - Opportunistic, a virulent plant symbionts. Nat. Rev. Microbiol. 2:43-56.

Hossain, M.A., M.M. Hoque, M.A. Khan, J.M.M. Islam and S. Naher. 2013. Foliar Application of radiation processed chitosan as plant growth promoter and anti-fungal agent on tea plants. Inter. Jour. of Sci. and Eng. Res. 4(8):1693-1698.

Howell, C.R. 2003. Mechanisms employed by Trichoderma species in the biological control of plant diseases: The history and evolution of current concepts. Plant Dis. 87:4-10.

Ikediobi, C.0. 1985. Biochemistry and physiology of yam storage. In advances in yam research, 109 - 141, G. Osuji ed. Biochemical society of Nigeria. 
Islam, M.S., M. Ali and I. Ahmad. 2013. In vitro study on the biocontrol activity of Trichoderma against Phomopsis theae petch, infecting collar rot of tea in Bangladesh. International Journal of Tea Science. 9(1):28-31.

Islam, M.S., and S.M.A. Haque. 2001. An assignment on methods in plant pathology requirement of partial fulfillment of the degree of Master of science in Plant Pathology, Bangladesh Agricultural University, Mymensingh.

Kim, D.J., J.M. Baek, P. Uribe, C.M. Kenerley and D.R. Cook. 2002. Cloning and characterization of multiple glycosyl hydrolase genes from Trichoderma virens. Curr. Genet. 40: 374-384.

Kuberan, T., R.S. Vidhyapallavi, A. Balamurugan, P. Nepolean, R. Jayanthi and R. Premkumar. 2012. Isolation and biocontrol potential of phylloplane Trichoderma against Glomerella cingulata in tea. J. Agri. Tech. 8(3):1039-1050.

Lorito, M., S.L. Woo, M. Dambrosio, G.E. Harman, C.K. Hayes, C.P. Kubicek and F. Scala. 1996. Synergistic interaction between cell wall degrading enzymes and membrane affecting compounds. Mol. PlantMicrobe Interact. 9:206-213.

Papavizas, G.C. 1985. Trichoderma and Gliocladium: Biology, ecology and potential for biocontrol. Annual Review of Phytopathol. 23:23-54.

Pozo, M.J., J.M. Baek, J.M. Garcia and C.M. Kenerley. 2004. Functional analysis of tvsp1, a serine proteaseencoding gene in the biocontrol agent Trichoderma virens. Fungal Genet. Biol. 41, 336348.

Premkumar, R. and U.I. Baby. 2005. Recommendations on the control of root and stem diseases of tea. Handbook of Tea Culture Section. 15-16.

Tasiwal, V., V.I. Benagi, Yashoda, R. Hedge, B.C. Kamanna and R.K. Naik. 2009. In vitro evaluation of botanicals, bioagents and fungicides against anthracnose of papaya caused by $C$. gloeosporioides (Penz.) Penz. \& Sacc.

Wiest, A., D. Grzegorski, B.W. Xu, C. Goulard, S. Rebuffat, D.J. Ebbole, B. Bodo and C. Kenerley. 2002. Identification of peptaibols from Trichoderma virens and cloning of a peptaibol synthetase. J. Biol. Chem. 277:20862-20868. 